Brazilian Journal

of Chemical

ISSN 0104-6632

Engineering

Printed in Brazil

www.scielo.br/bjce

Vol. 34, No. 04, pp. 985 - 996, October - December, 2017

$($ (c) $)$ EY

dx.doi.org/10.1590/0104-6632.20170344s20160417

\title{
THE EFFECT OF TEMPERATURE ON THE EFFICIENCY OF AEROBIC BIODEGRADATION OF SUGAR BEET DISTILLERY STILLAGE: REMOVAL OF POLLUTION LOAD AND BIOGENS
}

\author{
K. Lutosławski ${ }^{1, *}$, E. Cibis ${ }^{1}$ and M. Krzywonos ${ }^{1}$ \\ ${ }^{1}$ Department of Bioprocess Engineering, Wrocław University of Economics, Komandorska 118/120, 53-345 Wrocław, Poland. \\ "Corresponding author: E-mail krzysztof.lutoslawski@ue.wroc.pl; Phone: +48713680257; Fax +48713680753
}

(Submitted: July 15, 2016; Accepted: September 6, 2016)

\begin{abstract}
Beet stillage is a high-strength effluent from the production of ethanol from sugar beet. A large annual volume of sugar beet stillage requires finding new effective ways for its utilization. The aim of the study was to investigate the effect of temperature on the efficiency of aerobic biodegradation of beet stillage. Biodegradation was carried out for 168 hours in a stirred-tank reactor with a working volume of $5 \mathrm{~L}$ at $27^{\circ} \mathrm{C}, 36^{\circ} \mathrm{C}, 45^{\circ} \mathrm{C}, 54^{\circ} \mathrm{C}$ and $63^{\circ} \mathrm{C}$. All experiments were performed at uncontrolled $\mathrm{pH}$, aeration of $1.0 \mathrm{vvm}$ and of $900 \mathrm{rpm}$. The effectiveness of biodegradation was determined by the extent of removal of $\mathrm{SCOD}_{\text {sum }}(\mathrm{COD}$ determined after suspended solids separation and theoretical COD of betaine), $\mathrm{BOD}_{5}$ and TOC. Studies have shown that, under mesophilic conditions, the extents of reduction of $\mathrm{SCOD}_{\text {sum }}, \mathrm{BOD}_{5}$ and TOC were statistically significantly $(\mathrm{p} \leq 0.05)$ higher than under thermophilic conditions. Within the range of $27-36^{\circ} \mathrm{C}$, the highest reduction in $\mathrm{SCOD}_{\text {sum }}(79.2-79.9 \%), \mathrm{BOD}_{5}(98.4-99 \%)$ and $\mathrm{TOC}(76.1-77.3 \%)$ was obtained. Additionally, at the temperature of $36^{\circ} \mathrm{C}$, the highest reduction in total nitrogen $(56.4 \%)$ and total phosphorus $(58 \%)$ was achieved. Aerobic biodegradation allows for efficient treatment of sugar beet distillery stillage (preferably at $\left.36^{\circ} \mathrm{C}\right)$.
\end{abstract}

Keywords: sugar beet, distillery stillage, aerobic biodegradation, thermo- and mesophilic process, Bacillus species.

\section{INTRODUCTION}

Depleting fossil fuel resources have increased interest in renewable sources of energy, including biofuels. The most popular among them is bioethanol, whose global production in 2015 reached the level of 98 billion litres (REN21, 2016). The main problem associated with the production of this biofuel is environmentally harmful waste (stillage), due to its high pollution load. For one litre of ethanol produced, there are up to ten litres of stillage (Lata et al., 2002). Depending on the raw material used to produce bioethanol, COD of stillage ranges from $10 \mathrm{~g} \mathrm{O}_{2} / \mathrm{L}$
(España-Gamboa et al., 2011; Kharayat, 2012) to more than $100 \mathrm{~g} \mathrm{O}_{2} / \mathrm{L}$ (Robles-González et al., 2012).

For the production of ethanol various types of plant materials containing sugar (most commonly sugar cane, sugar beets, including molasses) or starch (mainly corn, wheat, barley and rye) are used (Sánchez and Cardona, 2008). In Europe, due to the existing natural and climatic conditions, the most common material for the production of fuel ethanol is sugar beet. In 2014, European production of ethanol from sugar beet rose to the level of approx. 1.1 billion litres (USDA, 2015). It can therefore be estimated that, at this rate of production, it annually requires

\footnotetext{
* To whom correspondence should be addressed
} 
utilization of over 10 billion litres of beet stillage. For this reason and due to the current restrictive environmental regulations, beet stillage requires finding various effective methods of its disposal.

In most research on sugar-based stillage (vinasse) only a few methods are presented. Some research shows that vinasse, directly or after concentration, can be used for fertilization of fields and meadows (Lewicki, 2001; Decloux and Bories, 2002; España-Gamboa et al., 2011; Fuess and Garcia, 2014). However, there is a difficulty for the utilization of stillage as a fertilizer due to the seasonal plant growth and limited agricultural land. Another method is the use of vinasse for the production of animal feed (Lewicki, 2001; Decloux et al., 2002). However, the lower (compared to starch-based stillage) nutritional value of vinasse (Lewicki, 2001) in combination with its high content of potassium (Decloux et al., 2002), as well as the limited number of animals to be fed, reduces the possibility for the direct utilization of vinasse. The limitations of the above mentioned methods prevent the utilization of the yearly amounts of stillage. The solution to this problem is to treat the stillage as wastewater and subject it to biodegradation in an aerobic or anaerobic manner.

Anaerobic digestion of stillage has been used on an industrial scale. An important advantage of an anaerobic process is the ability to produce biogas (biomethane) as renewable energy from organic waste. In France, a major producer of ethanol from sugar beet, some distilleries with biogas production units have been based on beet stillage methanization (Tereos, 2014). The anaerobic treatment of vinasse has also been used in India, where ethanol is usually produced from sugar cane and cane molasses (Rais and Sheoran, 2015). It should be noted, however, that a high content of pollutants present in this kind of wastewater works as an inhibitor for the anaerobic process, thereby reducing its efficiency. To prevent this, a frequently used solution is to dilute the stillage (Wilkie et al., 2000). According to the literature single-stage, full-scale anaerobic systems enable the removal of the COD of stillage loads from $24 \%$ (Nandy et al., 2002) to $85 \%$ (Decloux and Bories, 2002) for COD ranging from, respectively, 42 to $25 \mathrm{~g} \cdot \mathrm{O}_{2} / \mathrm{L}$. Even more effective treatments of this type of wastewater are multi-stage systems, where one of the stages is often an aerobic process (Fuess and Garcia, 2014). For example, in the anaerobic-aerobic stillage treatment on an industrial scale, a COD reduction of $90 \%$ was achieved (Akarsubasi et al., 2006).

However, as far as the authors are aware, there are no reports in the literature regarding the biodegradation of beet stillage through aerobic methods. It became a prerequisite for the authors to run the tests in order to establish the optimum temperature for the efficient aerobic biodegradation of beet stillage in terms of removal of the pollutant load (expressed as $\mathrm{COD}, \mathrm{BOD}_{5}$ and TOC) and biogenic elements (nitrogen and phosphorus). The effectiveness of aerobic processes has been confirmed by studies on the utilization of beet molasses vinasse (RyznarLuty et al., 2015), wheat stillage (Krzywonos et al., 2010) and corn, rye or potato stillage (Cibis, 2004). The maximum removal of pollutants expressed as the reduction in COD ranged from $75.9 \%$ (rye stillage) to $92.8 \%$ (wheat stillage).

\section{MATERIALS AND METHODS}

\section{Microorganisms}

In the experiments, a mixed culture of thermophilic and mesophilic bacteria of the genus Bacillus was used: two of them belong to the species $B$. circulans, and five strains corresponding, respectively, to the species $B$. laterosporus, B. filicolonicus, B. stearothermophilus, B. acidocaldarius and B. licheniformis (Cibis et al., 2004).

The activity of the bacterial culture was maintained in the bioreactor (scrubber) without stirring with a working volume of $0.5 \mathrm{~L}$ aerated at a rate of $1.0 \mathrm{vvm}$ (volume of air/ (volume of the medium $\times$ min)), and placed in an incubator maintained at the temperature of $45 \pm 2^{\circ} \mathrm{C}$. Periodically, after 3 days of adaptation the culture was inoculated onto a fresh stillage medium $(0.5 \mathrm{~L})$ (prepared according to the procedure described in the next section). The initial $\mathrm{pH}$ value $\left(\mathrm{pH}_{0}\right)$ of the medium was 7.5. The $\mathrm{pH}_{0}$ was adjusted using $33 \% \mathrm{NaOH}$, and it was not controlled during the bacterial incubation. The volume of the inoculum used was $20 \mathrm{~mL}$. All experiments were performed with the inoculum from an aerated scrubber, which contained a three-day old (after inoculation) bacterial culture.

\section{Preparation of the sugar beet stillage}

The sugar beet stillage which was used in the study came from Manufacturing Trade Enterprise Rol-Mi-Go Ltd. located in Jaśkowice Legnickie, Poland. Before its use, the stillage was filtered through a filter paper to separate the solid fraction from it. The chemical composition of the beet stillage after filtration is summarized in Table 1 .

This stillage was characterized by its dark-brown colour, low $\mathrm{pH}$ and high pollution load expressed as $\mathrm{SCOD}_{\text {sum }}$ (soluble COD determined by the dichromatic method +the theoretical COD of betaine $\left(2.097 \mathrm{~g} \mathrm{O}_{2} / \mathrm{L}\right)$ ), $\mathrm{BOD}_{5}$ and TOC (Table 1). The main sources of carbon in the beet stillage were reducing substances, organic acids and glycerol. Of the organic acids, lactic acid, glycolic acid, acetic acid, and pyroglutamic acid were observed in the largest quantities. The stillage also contained betaine, as well as biogenic elements, i.e., nitrogen and phosphorus (Table 1), which are important from the point of view of its biological degradation. The stillage medium, prepared both for supporting the activity of the bacteria and for biodegradation, was boiled for 15 minutes in order to eliminate possible contamination. After cooling, the liquid volume which evaporated during the cooking was replaced 
Table 1. Characterization of sugar beet distillery stillage.

\begin{tabular}{|c|c|}
\hline Parameter $^{\mathrm{a}}$ & Value \\
\hline $\mathrm{pH}$ & $5.25 \pm 0.01 *$ \\
\hline Density $\left({ }^{\circ} \mathrm{Blg}\right)$ & $5.50 \pm 0.10$ \\
\hline Suspended solids (SS) (g/L) & $1.76 \pm 0.13$ \\
\hline SCOD (soluble chemical oxygen demand) $\left(\mathrm{g} \mathrm{O}_{2} / \mathrm{L}\right)$ & $48.30 \pm 0.73$ \\
\hline $\mathrm{SCOD}_{\text {sum }}{ }^{\mathrm{b}}\left(\mathrm{g} \mathrm{O}_{2} / \mathrm{L}\right)$ & $50.10 \pm 0.82$ \\
\hline $\mathrm{BOD}_{5}$ (five-day biological oxygen demand) $\left(\mathrm{g} \mathrm{O}_{2} / \mathrm{L}\right)$ & $15.50 \pm 1.03$ \\
\hline TOC (total organic carbon) $(\mathrm{g} / \mathrm{L})$ & $13.02 \pm 0.94$ \\
\hline Reducing substances with hydrolysis (g/L) & $14.29 \pm 0.35$ \\
\hline Reducing substances without hydrolysis (g/L) & $5.38 \pm 0.09$ \\
\hline Sum of organic acids $(g / L)$ & $12.06 \pm 0.71$ \\
\hline Lactic acid (g/L) & $4.49 \pm 0.40$ \\
\hline Glycolic acid (g/L) & $2.52 \pm 0.23$ \\
\hline Acetic acid (g/L) & $1.29 \pm 0.12$ \\
\hline Pyroglutamic acid (g/L) & $1.12 \pm 0.09$ \\
\hline Isobutyric acid (g/L) & $0.92 \pm 0.11$ \\
\hline Butyric acid (g/L) & $0.83 \pm 0.06$ \\
\hline Formic acid $(\mathrm{g} / \mathrm{L})$ & $0.82 \pm 0.07$ \\
\hline Propionic acid (g/L) & $0.050 \pm 0.004$ \\
\hline Citric acid (g/L) & $0.010 \pm 0.002$ \\
\hline Tartaric acid $(\mathrm{g} / \mathrm{L})$ & $0.010 \pm 0.002$ \\
\hline Succinic acid $(g / L)$ & $0.00 \pm 0.00$ \\
\hline Glycerol (g/L) & $3.08 \pm 0.11$ \\
\hline Betaine (g/L) & $0.86 \pm 0.11$ \\
\hline Total nitrogen $(\mathrm{g} / \mathrm{L})$ & $1.512 \pm 0.060$ \\
\hline Ammonia nitrogen $(\mathrm{g} / \mathrm{L})$ & $0.154 \pm 0.015$ \\
\hline Total phosphorus (g/L) & $0.290 \pm 0.007$ \\
\hline Phosphate phosphorus (g/L) & $0.199 \pm 0.003$ \\
\hline
\end{tabular}

*Values following the sign " \pm " denote standard deviation, $n=3$.

${ }^{a}$ Besides $\mathrm{pH}$, density and suspended solids, the parameters were determined after suspended solids separation.

${ }^{\mathrm{b}}$ SCOD determined by the dichromate method + the theoretical COD of betaine.

with distilled water. The stillage was not diluted or enriched with additional biogenic compounds. The initial $\mathrm{pH}$ of the stillage used for biodegradation was $\mathrm{pH}_{0}=8.0$, and it was adjusted using $33 \% \mathrm{NaOH}$. The $\mathrm{pH}$ values were adopted from earlier studies in the Department of Bioprocess Engineering at the Wrocław University of Economics (Ryznar-Luty et al., 2015).

\section{Biodegradation processes}

Batch biodegradation processes were conducted for 168 hours in a 5-L working volume stirred-tank reactor (STR) of Biostat $\AA$ B type (B. Braun Biotech International, Germany) with the rotational speed of the stirrer $900 \mathrm{r} /$ min and aeration of $1.0 \mathrm{vvm}$. The volume of the stillage in the fermenter was $4.7 \mathrm{~L}$ (including $0.2 \mathrm{~L}$ of bacterial inoculum, prepared according to the procedure described in the section "Microorganisms"). The processes were carried out without $\mathrm{pH}$ control at $27^{\circ} \mathrm{C}, 36^{\circ} \mathrm{C}, 45^{\circ} \mathrm{C}, 54^{\circ} \mathrm{C}$ and $63^{\circ} \mathrm{C}$.

\section{Analytical methods}

The number of bacterial cells was determined using a haemocytometer (Thoma chamber, dimensions $0.05 \times 0.05 \times$ $0.1 \mathrm{~mm}$ ). The contents of the suspended solids (SS) obtained after the centrifugation of the sample for 40 minutes at the speed of $18,500 \times g\left(4 \mathrm{~K} 15\right.$, Sigma ${ }^{\circledR}$ Laborzentrifugen $\mathrm{GmbH}$, Germany) was determined gravimetrically (APHA, 1992). The supernatant was collected and frozen for analysis. Chemical oxygen demand (COD), five-day biological oxygen demand $\left(\mathrm{BOD}_{5}\right)$, total organic carbon (TOC), total phosphorus and phosphate phosphorus were determined spectrophotometrically (spectrophotometer DR5000, Hach-Lange) using cuvette tests on the HachLange (DrLange, 2000). COD was measured both in the 
supernatant (SCOD) and in the non-centrifuged medium (TCOD). For the measurement of organic acids content, the HPLC method was used (column type, Phenomenex ROA Organic Acid, column size, $7.8 \mathrm{~mm}$ i.d. $\times 300 \mathrm{~mm}$; eluent, $5 \mathrm{mM} \mathrm{H}_{2} \mathrm{SO}_{4}$; flow rate, $0.5 \mathrm{~mL} / \mathrm{min}$; temperature, $40^{\circ} \mathrm{C}$ ). The content of reducing substances was determined by the Lane-Eynon method, which consisted of the titration of the sample for discoloration in an alkaline medium with copper sulphate and iron-potassium cyanide at high temperature (approx. $100^{\circ} \mathrm{C}$ ) (McDonald, 1954). The total nitrogen content was determined by the Kjeldahl method (APHA, 1992) using the C.Gerhardt GmbH \& Co. KG apparatus (Germany), and ammonia nitrogen via distillation (APHA, 1992) using the Parnas apparatus. Glycerol content was determined spectrophotometrically (Ogorodnik and Stupakova, 1981). For the betaine content measurement a colorimetric method specified by Focht et al. (1956) was used. Since the determination of COD by the dichromate method does not detect betaine, the $\mathrm{COD}_{\mathrm{su}}$ value was determined as the sum of the obtained COD value and the theoretical COD value of betaine (2.097 $\mathrm{g} \mathrm{O}_{2} / \mathrm{g}$ of betaine).

\section{RESULTS}

\section{Efficiency and rate of biodegradation}

Compared to the thermophilic conditions, the mesophilic processes produced a statistically significantly (for $\mathrm{p} \leq 0.05$ ) higher efficiency of biodegradation assessed by the extents of reduction of the pollution load (Table 2). The processes which had the largest increase of biomass $\left(27\right.$ and $36^{\circ} \mathrm{C}$ ), yielded the greatest reduction in, e.g., $\mathrm{SCOD}_{\text {sum }}$, $\mathrm{SCOD}$ determined by the dichromatic method
+ theoretical COD of betaine), $\mathrm{BOD}_{5}$ and TOC determined after the separation of suspended solids. In addition, at 27 and $36^{\circ} \mathrm{C}$, as well as at $45^{\circ} \mathrm{C}$, there was a faster utilization of pollutants expressed as SCOD than there was at a higher temperature (Fig. 1).

At $45^{\circ} \mathrm{C}$, the SCOD removal accounted for $90 \%$ of the value at $62 \mathrm{~h}$, while at the temperatures of $54^{\circ} \mathrm{C}$ and $63^{\circ} \mathrm{C}$ it did not occur until $103 \mathrm{~h}$. As a result, the rate of SCOD removal was more than double, in a process carried out at the temperature of $45^{\circ} \mathrm{C}\left(0.49 \mathrm{~g} \mathrm{O}_{2} /(\mathrm{L} \times \mathrm{h})\right)$, than in processes carried out at $54^{\circ} \mathrm{C}$ and $63^{\circ} \mathrm{C}$ (respectively 0.20 and $\left.0.23 \mathrm{~g} \mathrm{O}_{2} /(\mathrm{L} \times \mathrm{h})\right)($ Table 2$)$. The process conducted at $45^{\circ} \mathrm{C}$ was also characterized by a short period of lag phase and the largest rate of growth of the bacterial cells (data not presented). However, compared to the results obtained at the temperature of 27 and $36^{\circ} \mathrm{C}$, the reductions in $\mathrm{SCOD}_{\text {sum }}, \mathrm{BOD}_{5}$ and $\mathrm{TOC}$ were lower by several percent at $45^{\circ} \mathrm{C}$ (Table 2).

\section{Removal of organic substances}

The highest effectiveness of biodegradation at 27 and $36^{\circ} \mathrm{C}$ was achieved by the complete assimilation of organic acids and the high extent of reducing substances removal (measured before (84.1\%) and after hydrolysis (86.3\%)), as well as the high extent of glycerol removal (91.4\%) (Table 3). It should be added that the total assimilation of betaine by the bacteria also contributed to the increase of efficiency of biodegradation in mesophilic processes.

The reason for the low efficiency in experiments carried out at a temperature $\geq 45^{\circ} \mathrm{C}$ was first of all a reduction in the extent of organic acids removal by up to $20.7 \%$. In addition, the efficiency of biodegradation at the temperatures of $54^{\circ} \mathrm{C}$ and $63^{\circ} \mathrm{C}$ was adversely affected by the lowest extent of assimilation of the

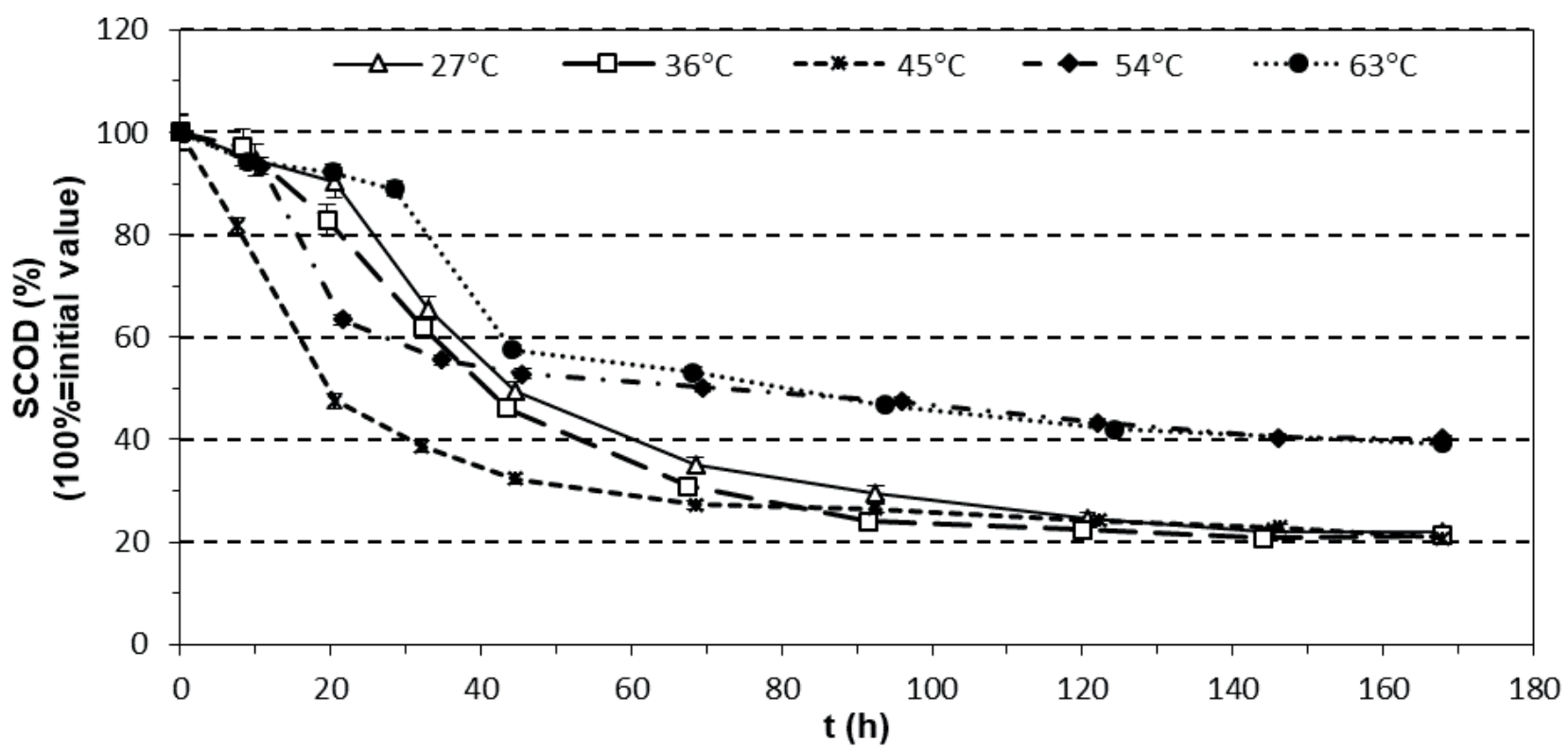

Figure 1. Effect of temperature on SCOD removal during biodegradation of sugar beet distillery stillage. 
reducing substances determined after hydrolysis, amounting respectively to 46.9 and $59 \%$ (Table 3 ).

The Bacillus bacteria culture used glycerol (Fig. 2a) as the main carbon source, followed by the reducing substances (Fig. 2b). The biosynthesis of organic acids visible in Figure 2c was most likely the reason for their slowest assimilation. The decrease in the total content of organic acids in the medium was generally observed not earlier than after $45 \mathrm{~h}$ of the process duration (Fig. 2c). The fastest assimilation of organic acids was observed in the experiment at $36^{\circ} \mathrm{C}$, and in this process after $91 \mathrm{~h}$ they were completely utilized (Fig. 2c).

Among the organic acids, the determined acids: lactic, pyroglutamic and isobutyric acids were assimilated in

Table 2. Effect of temperature on sugar beet distillery stillage biodegradation.

\begin{tabular}{|c|c|c|c|c|c|}
\hline \multirow{2}{*}{ Parameter } & \multicolumn{5}{|c|}{ Temperature $\left({ }^{\circ} \mathrm{C}\right)$} \\
\hline & 27 & 36 & 45 & 54 & 63 \\
\hline SCOD removal (\%) & $78.0^{\mathrm{b}} \pm 0.9^{*}$ & $78.7^{b} \pm 0.6$ & $79.3^{b} \pm 0.6$ & $59.8^{c} \pm 0.5$ & $60.8^{c} \pm 0.5$ \\
\hline $\mathrm{SCOD}_{\text {sum }}$ removal (\%) & $79.2^{b} \pm 0.9$ & $79.9^{b} \pm 0.5$ & $76.7 \pm 0.8$ & $58.4^{c} \pm 0.8$ & $57.9^{c} \pm 0.8$ \\
\hline TCOD removal (\%) & $63.2^{\mathrm{b}} \pm 1.2$ & $64.6^{\mathrm{b}} \pm 1.2$ & $67.6 \pm 1.1$ & $52.6^{c} \pm 1.4$ & $53.6^{c} \pm 1.2$ \\
\hline $\mathrm{TCOD}_{\text {sum }}$ removal (\%) & $65.1^{\mathrm{b}} \pm 1.1$ & $66.6^{\mathrm{b}} \pm 1.1$ & $65.5^{\mathrm{b}} \pm 1.2$ & $51.7^{\mathrm{c}} \pm 1.5$ & $51.1^{\mathrm{c}} \pm 1.3$ \\
\hline $\mathrm{BOD}_{5}$ removal $(\%)$ & $99.0 \pm 0.1$ & $98.4 \pm 0.2$ & $90.4 \pm 0.5$ & $76.9 \pm 1.7$ & $71.2 \pm 1.5$ \\
\hline TOC removal (\%) & $77.3^{b} \pm 2.1$ & $76.1^{\mathrm{b}} \pm 2.5$ & $71.0 \pm 1.8$ & $57.7^{\mathrm{c}} \pm 3.0$ & $55.1^{\mathrm{c}} \pm 1.5$ \\
\hline $\begin{array}{l}\text { Time after which } 90 \% \text { of the overall reduction in } \\
\text { SCOD was attained (h) }\end{array}$ & 91.5 & 73 & 62 & 103 & 103 \\
\hline SCOD removal rate $\left(\mathrm{gO}_{2} /(\mathrm{L} \times \mathrm{h})\right)^{\mathrm{a}}$ & 0.32 & 0.39 & 0.49 & 0.20 & 0.23 \\
\hline Total nitrogen removal (\%) & $43.3 \pm 3.3$ & $56.4^{\mathrm{b}} \pm 2.5$ & $56.1^{\mathrm{b}} \pm 2.6$ & $15.1^{\mathrm{c}} \pm 4.9$ & $17.7^{\mathrm{c}} \pm 4.8$ \\
\hline Ammonia nitrogen removal (\%) & $-8.3 \pm 12.3$ & $27.7 \pm 8.2$ & $56.0 \pm 5.0$ & $71.1^{\mathrm{b}} \pm 3.3$ & $71.9^{\mathrm{b}} \pm 3.2$ \\
\hline Total phosphorus removal (\%) & $55.4^{\mathrm{b}} \pm 3.5$ & $58.0^{\mathrm{b}} \pm 3.3$ & $32.8^{c} \pm 5.2$ & $40.7^{c} \pm 4.6$ & $32.1^{\mathrm{c}} \pm 5.3$ \\
\hline Phosphate phosphorus removal (\%) & $50.3 \pm 2.5$ & $60.2 \pm 2.0$ & $34.2 \pm 3.3$ & $44.5 \pm 2.6$ & $22.4 \pm 3.8$ \\
\hline Final number of cells formed $\left(\times 10^{9} / \mathrm{mL}\right)$ & $6.3 \pm 0.5$ & $2.8^{\mathrm{b}} \pm 0.2$ & $2.2 \pm 0.2$ & $3.2^{\mathrm{b}} \pm 0.3$ & $3.2^{\mathrm{b}} \pm 0.3$ \\
\hline Final amount of SS formed $(\mathrm{g} / \mathrm{L})$ & $4.1 \pm 0.6$ & $2.9 \pm 0.3$ & $1.4^{\mathrm{b}} \pm 0.4$ & $1.6^{\mathrm{b}} \pm 0.4$ & $1.9^{\mathrm{b}} \pm 0.3$ \\
\hline $\mathrm{Y}_{\mathrm{SS}}((\mathrm{g}$ final SS formed/g SCOD sum removed $) \cdot 100 \%)$ & $11.9 \pm 1.7$ & $8.7^{\mathrm{b}} \pm 1.1$ & $4.0 \pm 1.2$ & $6.9^{\mathrm{b}} \pm 1.4$ & $7.0^{\mathrm{b}} \pm 1.3$ \\
\hline
\end{tabular}

*Values following the sign \pm denote standard deviation, $\mathrm{n}=3$. The sign minus indicates an increase in the content of the pollutant.

${ }^{a}$ The value of this parameter was calculated for the point in time after which $90 \%$ of the overall reduction in SCOD was attained.

${ }^{b, c}$ Differences in the values denoted by the same letter in the same row are statistically insignificant for $\mathrm{p} \leq 0.05$.

Table 3. Effect of temperature on the removal of the main organic compounds from the beet stillage.

\begin{tabular}{lccccc}
\hline \multirow{2}{*}{ Removal (\%) } & \multicolumn{5}{c}{ Temperature $\left({ }^{\circ} \mathrm{C}\right)$} \\
\cline { 2 - 6 } & $\mathbf{2 7}$ & $\mathbf{3 6}$ & $\mathbf{4 5}$ & $\mathbf{5 4}$ & $\mathbf{6 3}$ \\
\hline Reducing substances with hydrolysis & $86.3 \pm 0.6^{*}$ & $81.8 \pm 0.7$ & $79.7 \pm 0.8$ & $46.9 \pm 2.2$ & $59.0 \pm 1.7$ \\
Reducing substances without hydrolysis & $84.1^{\mathrm{b}} \pm 0.5$ & $83.8^{\mathrm{b}} \pm 0.5$ & $81.9 \pm 0.5$ & $76.7^{\mathrm{c}} \pm 0.7$ & $77.2^{\mathrm{c}} \pm 0.7$ \\
Sum of organic acids & $100.0 \pm 0.0$ & $100.0 \pm 0.0$ & $79.3 \pm 1.1$ & $87.7 \pm 0.8$ & $82.2 \pm 1.1$ \\
Lactic acid & $100.0 \pm 0.0$ & $100.0 \pm 0.0$ & $100.0 \pm 0.0$ & $100.0 \pm 0.0$ & $100.0 \pm 0.0$ \\
Glycolic acid & $100.0 \pm 0.0$ & $100.0 \pm 0.0$ & $96.4 \pm 0.4$ & $75.9 \pm 2.7$ & $63.6 \pm 4.1$ \\
Acetic acid & $100.0 \pm 0.0$ & $100.0 \pm 0.0$ & $73.3^{\mathrm{b}} \pm 3.5$ & $78.3^{\mathrm{b}} \pm 2.9$ & $52.2 \pm 6.3$ \\
Pyroglutamic acid & $100.0 \pm 0.0$ & $100.0 \pm 0.0$ & $100.0 \pm 0.0$ & $97.3^{\mathrm{b}} \pm 0.3$ & $97.5^{\mathrm{b}} \pm 0.3$ \\
Isobutyric acid & $99.4 \pm 0.1$ & $100.0 \pm 0.0$ & $100.0 \pm 0.0$ & $100.0 \pm 0.0$ & $92.0 \pm 0.9$ \\
Butyric acid & $100.0 \pm 0.0$ & $100.0 \pm 0.0$ & $-78.1 \pm 10.1$ & $100.0 \pm 0.0$ & $92.0 \pm 0.4$ \\
Formic acid & $100.0 \pm 0.0$ & $100.0 \pm 0.0$ & $81.4 \pm 2.2$ & $-14.6 \pm 13.8$ & $54.4 \pm 5.5$ \\
Propionic acid & $100.0 \pm 0.0$ & $100.0 \pm 0.0$ & $100.0 \pm 0.0$ & $100.0 \pm 0.0$ & $16.1 \pm 5.9$ \\
Glycerol & $88.1 \pm 0.6$ & $91.4 \pm 0.4$ & $76.5 \pm 1.2$ & $70.1 \pm 1.5$ & $96.5 \pm 0.2$ \\
Betaine & $100.0 \pm 0.0$ & $100.0 \pm 0.0$ & $22.8^{\mathrm{b}} \pm 14.4$ & $35.0^{\mathrm{b}} \pm 12.7$ & $0.0 \pm 0.0$ \\
\hline
\end{tabular}

*Values following the sign \pm denote standard deviation, $\mathrm{n}=3$. The sign minus indicates an increase in the content of the pollutant.

${ }^{b, c}$ Differences in the values denoted by the same letter in the same row are statistically insignificant for $\mathrm{p} \leq 0.05$. 


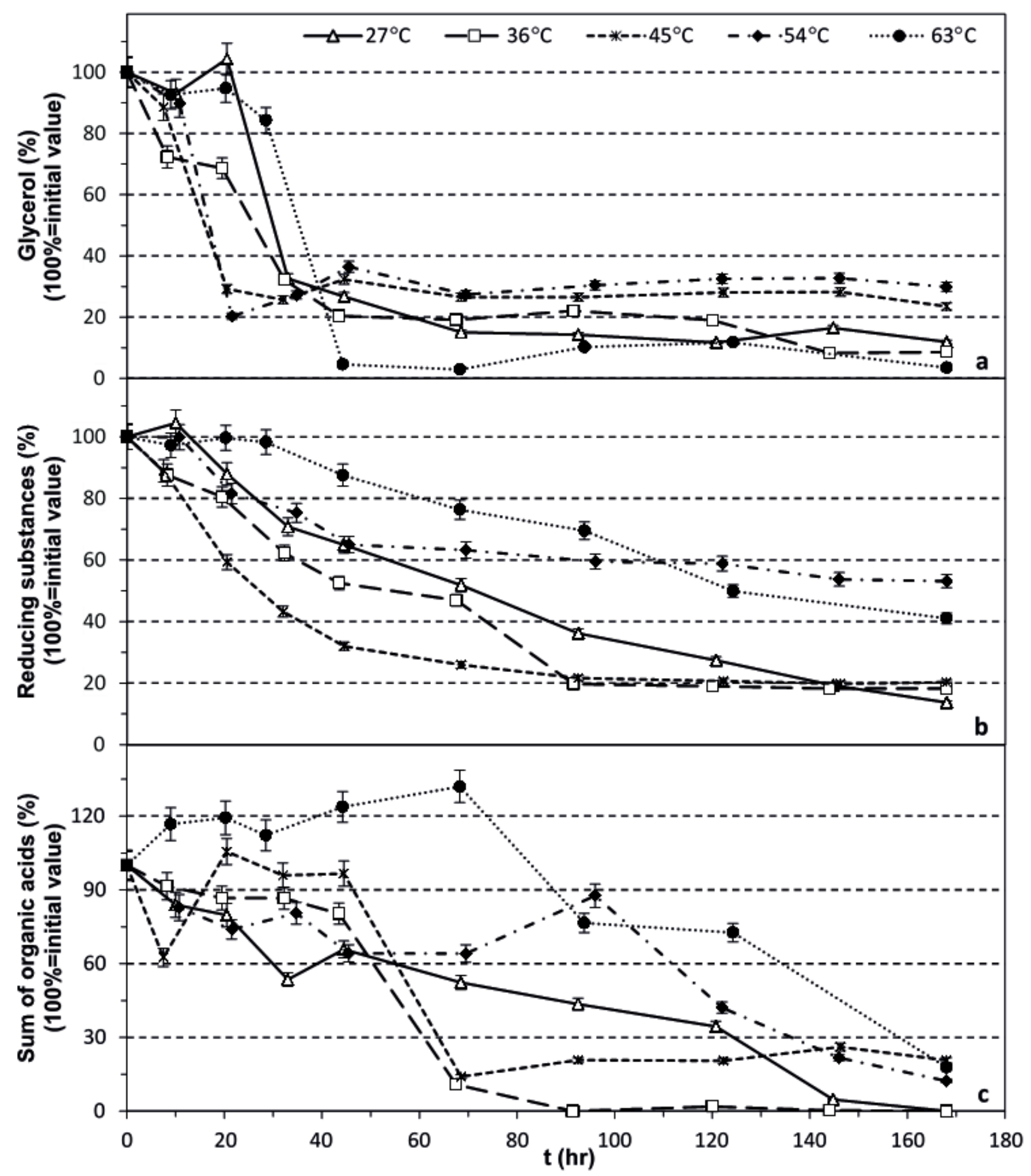

Figure 2. Biodegradation of glycerol (a), reducing substances with hydrolysis (b) and sum of organic acids (c) at various process temperatures.

the largest quantities by the bacteria. Lactic acid was completely removed in all experiments and pyroglutamic and isobutyric acids, depending on the temperature of the process, to the extent between, respectively, 97.3-100\% and $92-100 \%$ (Table 3 ).
The aforementioned phenomenon of biosynthesis of organic acids with the use of bacterial cultures was less noticeable in the mesophilic conditions than in thermophilic ones (Fig. 2c). The increase in the total content of organic acids was primarily affected by the synthesis of butyric 
acid. Depending on the temperature of biodegradation, the maximum synthesis of this acid (recorded between 35 and $44 \mathrm{~h}$ of the process) was between approx. 4 (at $27^{\circ} \mathrm{C}$ ) to approx. $10 \mathrm{~g} / \mathrm{L}$ (at $63^{\circ} \mathrm{C}$ ) (Fig. 3). Despite the large amounts of butyric acid synthesized during biodegradation it was removed from the stillage medium to an extent of no less than $92 \%$ (excluding the temperature of $45^{\circ} \mathrm{C}$ ) (Table 3).

\section{Removal of nitrogen and phosphorus}

The efficiency of biogenic elements removal from the stillage medium varied according to the biodegradation temperature. In processes when the highest removal of organic pollutants was observed at 27 and $36^{\circ} \mathrm{C}$, there was also the highest removal of nitrogen and phosphorus. The maximum extent of $\mathrm{N}$ total and $\mathrm{P}$ total removal, amounting to $56.4 \%$ and $58.0 \%$, respectively, was achieved during the stillage biodegradation at $36^{\circ} \mathrm{C}$ (Table 2). In turn, at higher temperatures $\left(54-63^{\circ} \mathrm{C}\right)$ there were recorded, apart from low extents of removal of the main organic pollutants from the stillage, also the lowest extents of removal of both nitrogen and phosphorus (Table 2).

During the biodegradation, in none of the experiments was the limitation of the process caused by a deficiency of any biogens (nitrogen or phosphorus) in the stillage medium (Fig. 4). It should be noted that the concentration of ammonia nitrogen in the first phase of bacterial activity during the rapid growth of cells gradually decreased, until a characteristic increase of its content in the medium was observed (Fig. 4a). Depending on the temperature of the biodegradation, the $\mathrm{N}-\mathrm{NH}_{4}$ concentration growth occurred between 68 and $124 \mathrm{~h}$ of the process (Fig. 4a). After that time, in the processes carried out at 27,36 and $45^{\circ} \mathrm{C}$ there was a stabilization of the ammonia nitrogen content in the medium, while at 54 and $63^{\circ} \mathrm{C}$ there was observed a decrease of its content in the stillage medium, which lasted until the end of the biodegradation process (Fig. 4a).

It follows that changes in the content of ammonia nitrogen in the medium are related not only to the synthesis of biomass, but also have a close relationship with the temperature of the process. The $\mathrm{NH}_{4}-\mathrm{N}$ content in the stillage medium also affects its $\mathrm{pH}$. In the medium with an alkaline $\mathrm{pH}$, ammonia nitrogen is released into the atmosphere as ammonia. This phenomenon occurs more quickly the higher the temperature of biodegradation and the higher the $\mathrm{pH}$ of the stillage medium.

Due to the high temperature of the process and the high $\mathrm{pH}$, the higher rate of volatilization of ammonia nitrogen in the form of $\mathrm{NH}_{3}$ into the atmosphere rather than the rate it is formed by the deamination of proteins was probably the reason for the rapid decrease in the ammonia nitrogen content in the medium at the end of biodegradation induced at high temperature $\left(54\right.$ and $\left.63^{\circ} \mathrm{C}\right)$. In turn, the final effect of biodegradation at a lower temperature $\left(27-45^{\circ} \mathrm{C}\right)$ was a similar rate of ammonia nitrogen volatilization into the atmosphere as $\mathrm{NH}_{3}$ and the rate of $\mathrm{N}-\mathrm{NH}_{4}$ formation, and as a result stabilization of the ammonia nitrogen content at a level of approx. $0.21 \mathrm{~g} / \mathrm{L}, 0.19 \mathrm{~g} / \mathrm{L}$ and $0.12 \mathrm{~g} / \mathrm{L}$, respectively, for the temp. of 27,36 and $45^{\circ} \mathrm{C}$ (Fig. 4a).

Finally, in the temperature range of $45-63^{\circ} \mathrm{C}$ there were more than twice as high extents of removal of the ammonia nitrogen from the medium than there was in the process carried out in the temp. of $36^{\circ} \mathrm{C}$, where the reduction in $\mathrm{NH}_{4}-\mathrm{N}$ concentration was $27.7 \%$. It should be added that, at the temperature of $27^{\circ} \mathrm{C}$, the $\mathrm{NH}_{4}-\mathrm{N}$ content in the stillage medium at the end of the process was even higher than in the beginning (Table 2).

Analysing all the time courses of the $\mathrm{P}_{-} \mathrm{PO}_{4}$ content (Fig. 4b) it can be assumed that the reason for the rise

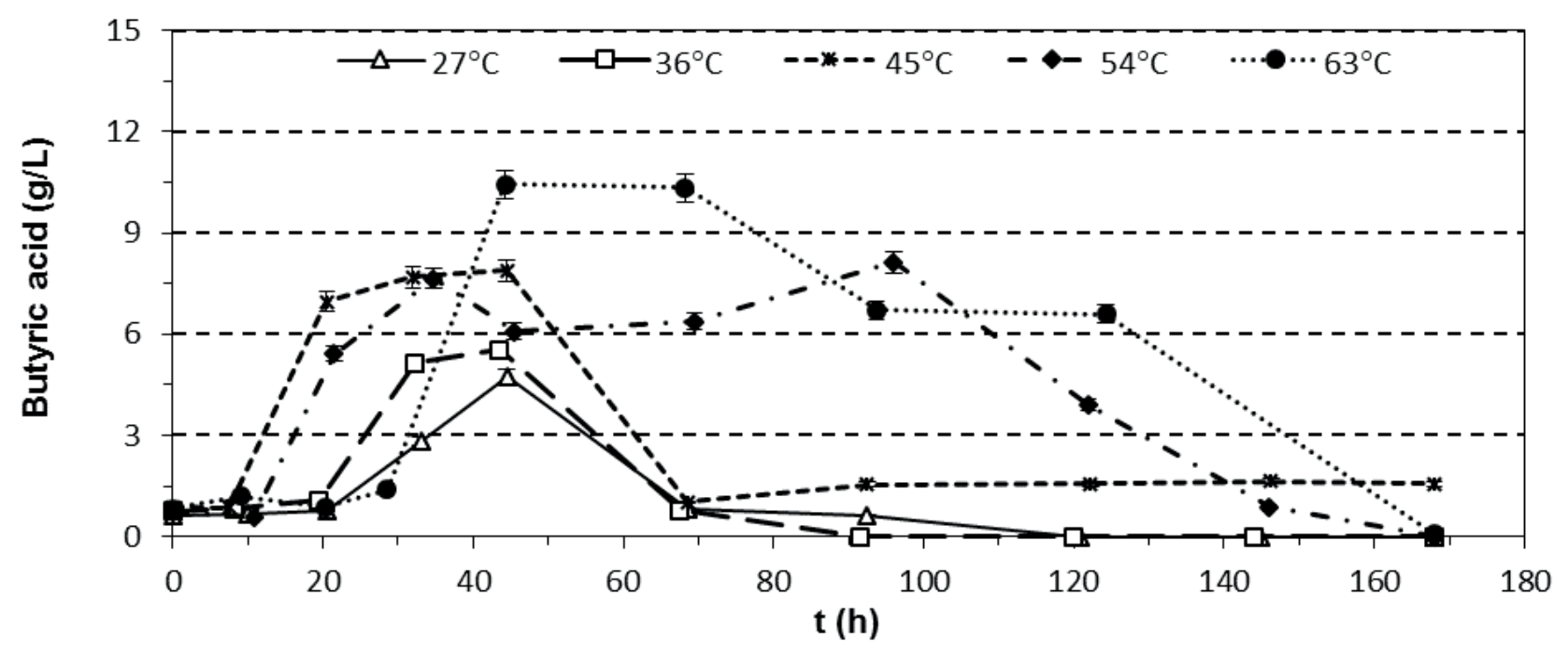

Figure 3. Synthesis and assimilation of butyric acid during biodegradation at various process temperatures. 


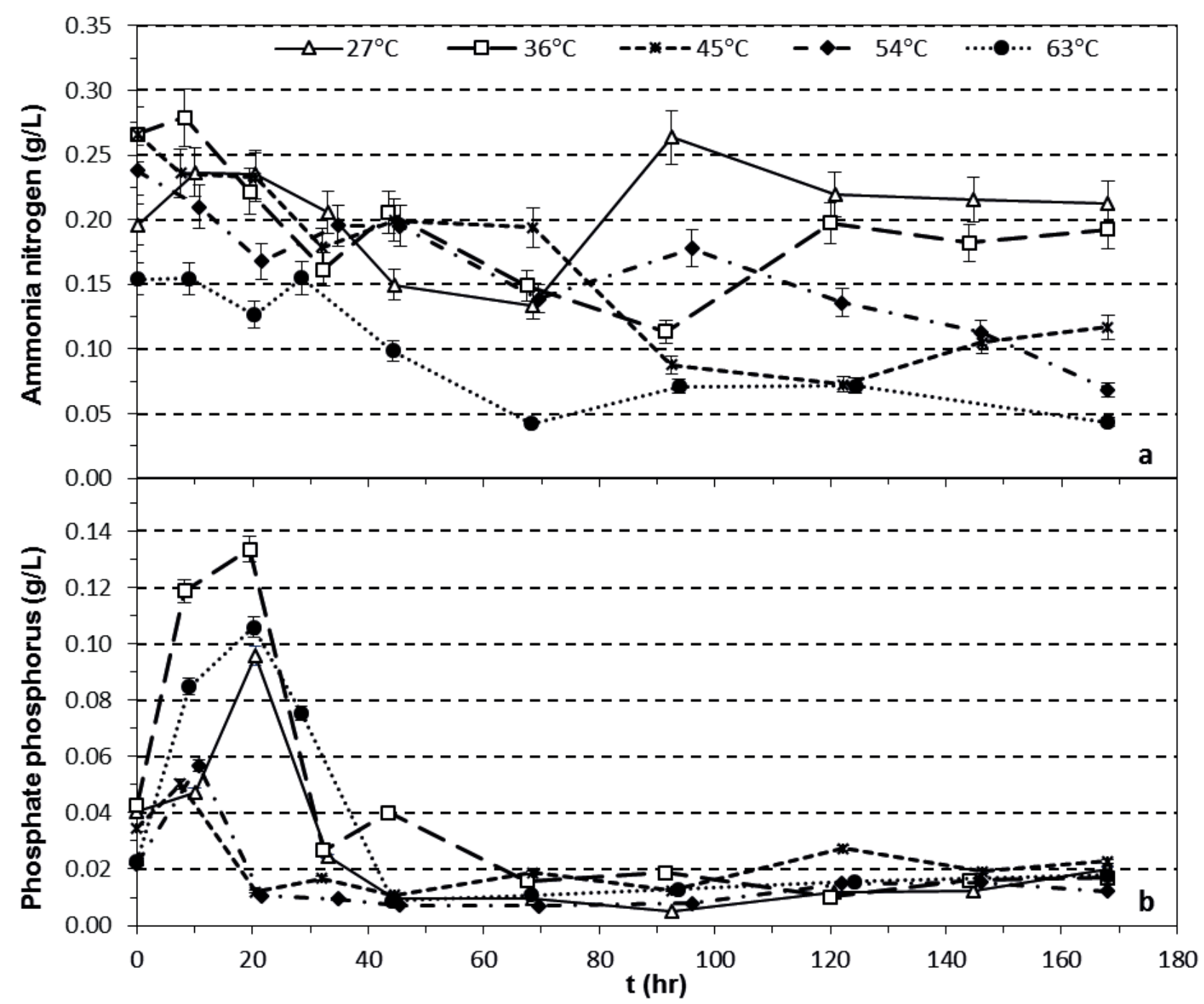

Figure 4. Ammonia nitrogen (a) and phosphate phosphorus (b) concentrations during biodegradation at various process temperatures.

of the phosphate phosphorus content in the first hours of the process, during the lag phase, was the hydrolysis of the suspended solids from the medium, caused mainly by the stirring system in the bioreactor. A particularly significant increase in the $\mathrm{P}_{-} \mathrm{PO}_{4}$ content occurred in the mesophilic processes and at $63^{\circ} \mathrm{C}$ (Fig. 4b). Then, in all the experiments, during the sharp increase in biomass, the phosphate phosphorus content rapidly decreased to the minimum range of $5-15 \mathrm{mg} / \mathrm{L}$ (Fig. 4b). It can therefore be assumed that the $\mathrm{P}_{-} \mathrm{PO}_{4}$ was then assimilated by the bacteria. In contrast, the autolysis of cells in the final phase of each process was probably the cause of a slight increase in the $\mathrm{P}_{-} \mathrm{PO}_{4}$ content with respect to the minimum content in the medium obtained during the biodegradation.

As in the case of the total phosphorus, phosphate phosphorus was removed from the stillage to a greater extent at the temperature corresponding to mesophilic conditions $\left(27\right.$ and $\left.36^{\circ} \mathrm{C}\right)$ rather than at the higher temperatures $\left(\geq 45^{\circ} \mathrm{C}\right)$. The highest extent of the removal of $\mathrm{P}-\mathrm{PO}_{4}(60.2 \%)$, as in the case of total phosphorus, was at $36^{\circ} \mathrm{C}$ (Table 2).

\section{Variations in dissolved oxygen tension and $\mathrm{pH}$}

Regardless of the biodegradation temperature, all experiments had two phases of bacterial activity. In the first phase, at the beginning of the processes there could be observed a sharp decrease in dissolved oxygen tension (DOT) (Fig. 5a), accompanied by acidification of the medium (Fig. 5b). In the second phase, along with the gradual decrease in the activity of the bacteria and the gradual increase in DOT content, there was an alkalization of the stillage medium until it reached a steady state. Depending on the biodegradation temperature, $\mathrm{pH}$ values in the steady state (achieved no earlier than after $110 \mathrm{~h}$ ) were set between 9.2-9.9 (Fig. 5).

The lowest content of both DOT (16.5\%) and the lowest $\mathrm{pH}(5.9)$ in the medium was observed (about $16 \mathrm{~h}$ ) in the 


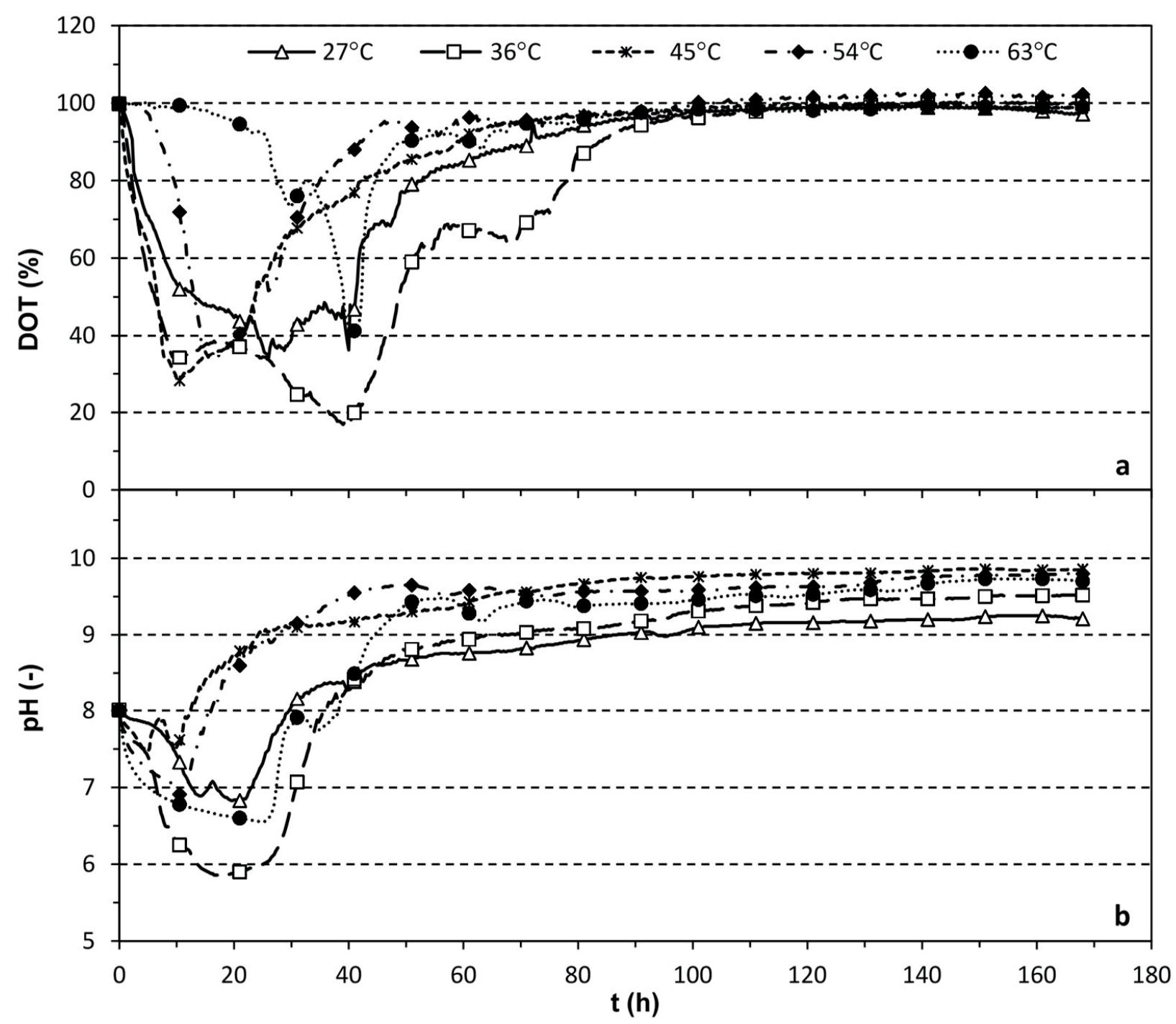

Figure 5. Variations in DOT (dissolved oxygen tension) (a) and $\mathrm{pH}$ (b) during biodegradation at various process temperatures.

experiment conducted at $36^{\circ} \mathrm{C}$ (Fig. 5); therefore, in the process with the highest efficiency of removal of pollution load, the chosen bacteria culture also showed the greatest activity during biodegradation.

\section{Biomass}

The high activity of the bacterial culture at $36^{\circ} \mathrm{C}$ was unrelated to the greatest amount of produced biomass which requires further processing after biodegradation. This is evidenced by the results presented in Table 2, indicating the amount of the produced biomass expressed as the final number of the bacterial cells formed, the final amount of suspended solids formed, and expressed as a ratio of the second parameter to the final amount of $\mathrm{SCOD}_{\text {sum }}$ removed $\left(\mathrm{Y}_{\mathrm{SS}}\right)$. Even smaller amounts of biomass than those at $36^{\circ} \mathrm{C}$ were produced at higher temperatures, and the lowest values of said parameters, i.e., respectively $2.2 \times 10^{9} / \mathrm{mL}, 1.4 \mathrm{~g} / \mathrm{L}$ and $4.0 \%$, were recorded at the temperature of $45^{\circ} \mathrm{C}$. However, the most important for the effective biodegradation extents of the removal of pollutants, expressed as $\mathrm{SCOD}_{\text {sum }}, \mathrm{BOD}_{5}$ and $\mathrm{TOC}$, were not among the highest at that point, as already mentioned in the section "Efficiency and rate of biodegradation".

\section{DISCUSSION}

The highest reduction in the organic matter content expressed as $\mathrm{SCOD}_{\text {sum }}$ and $\mathrm{BOD}_{5}$ amounted to $79.9 \%$ and $99.0 \%$, respectively (Table 2 ). High efficiency of aerobic biodegradation with the use of the same mixed culture of Bacillus bacteria as the one used in our present study was also obtained by the authors of works on the subject 
of treatment of distillery wastewater from other sugar materials as well as starch materials.

Comparable or higher extents of SCOD removal were obtained during batch biodegradation of beet molasses vinasse

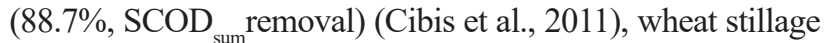
(92.8\%) (Krzywonos et al., 2010), potato (76.7-89.8\%) (Cibis et al., 2002, 2004; Krzywonos et al., 2009), corn (82.6\%) and rye stillage (84.6\%) (Cibis, 2004). A similar COD removal (81\%) with a different bacterial culture of the genus Bacillus was also obtained in the work by Jain et al. (2002) by aerobic treatment of the diluted effluent after the anaerobic biodegradation of cane molasses vinasse. Only several of the above mentioned authors demonstrate in their studies the extent of removal of the stillage pollutants expressed as $\mathrm{BOD}_{5}$. However, the over $99 \%$ reduction in $\mathrm{BOD}_{5}$ obtained by Cibis et al. (2011) is comparable to the value obtained in the present study (Table 2).

The positive results of biodegradation in the batch processes with the use of a mixed culture of Bacillus bacteria were also achieved in the case of other highstrength wastewater from the food industry. COD removal (of up to 93\%) higher than the one described in this study was obtained for biodegradation of whey (Kosseva et al., 2007), while a lower removal of this parameter was recorded during the biological treatment of wastewater from the potato industry (78\%) (Lasik et al., 2010) and meat industry (72\%) (Beaudet et al., 1990). Less favourable results of COD reduction were also obtained using other thermophilic and mesophilic aerobic bacteria for biological wastewater treatment from the pharmaceutical industry (62\%) (LaPara et al., 2001).

The efficiency of sugar beet stillage biodegradation was significantly affected by the temperature of the process. The mixed culture of Bacillus bacteria in mesophilic processes $\left(27-36^{\circ} \mathrm{C}\right)$ was characterized by a higher efficiency than in other experiments. Both in the studies described in this paper and those made by Cibis et al. (2011), during the biodegradation of beet molasses vinasse, the results of reduction in $\mathrm{COD}_{\text {sum }}, \mathrm{BOD}_{5}$ and $\mathrm{TOC}$ obtained at $27-36^{\circ} \mathrm{C}$ were at least a few percent higher than at the temperature above $36^{\circ} \mathrm{C}$. A similar effect of the temperature for biodegradation of the stillage with the use of the Bacillus bacteria on COD removal was observed by Krzywonos et al. (2009). In this case, during the batch biodegradation of potato stillage performed under mesophilic conditions a higher reduction of about $4 \%$ in COD was recorded than under thermophilic conditions.

The resulting highest efficiency of biodegradation of the beet stillage in terms of removal of the pollution load expressed as $\mathrm{COD}, \mathrm{BOD}_{5}$ and $\mathrm{TOC}$ at $27-36^{\circ} \mathrm{C}$ was not surprising. According to the data on the effect of temperature on the efficiency of distillery wastewater biodegradation by the mixed culture of Bacillus bacteria used in this study shows that both from the treatment of the beet molasses vinasse (86.4-88.7\%) (Cibis et al., 2011) and potato stillage (85.5 -89.1\%) (Krzywonos et al., 2009), the highest COD removal is achieved in the range of $30-45^{\circ} \mathrm{C}$.

The studies presented in this paper show that the highest efficiency of biodegradation, as assessed by $\mathrm{COD}_{\text {sum }}$ removal, achieved at $36^{\circ} \mathrm{C}$, was caused by total assimilation of organic acids, as well as a high extent of the removal of reducing substances determined after hydrolysis $(81.8 \%)$ and glycerol (91.1\%) (Table 3). Similar results for the removal of organic acids and reducing substances from the stillage were obtained in experiments carried out by Ryznar-Luty (2008) on beet molasses vinasse. It should be noted, however, that unlike the beet molasses vinasse, the main organic compound of the beet stillage used in this study was not betaine, since its content in beet stillage does not exceed $1 \mathrm{~g} / \mathrm{L}$ (Table 1). Comparable efficiency of the degradation of reducing substances determined after hydrolysis, organic acids and glycerol by the same cultures was also demonstrated by Krzywonos et al. $(2009,2010)$ during aerobic biodegradation of starch-based stillage. A similar efficiency for removal of reducing substances, as well as organic acids by using Bacillus culture was also characteristic of the biodegradation of wastewater from the potato industry (Lasik et al., 2010).

The phenomenon of acidification and subsequent stillage medium alkalization, present in all experiments, was also observed in aerobic batch biodegradation processes for beet molasses vinasse (Ryznar-Luty et al., 2015), as well as with wastewater from the dairy industry (Carta-Escobar et al., 2004) and the paper industry (Tiirola et al., 2003).

As was the case in the batch biodegradation experiments with the use of a mixed culture of Bacillus carried out by Ryznar-Luty et al. (2015), in this study the reason for the acidification of the stillage medium was also biosynthesis of organic acids, and the alkalization of the medium in the bioreactor was due to deamination of proteins, and due to the assimilation of organic acids including those synthesized by the bacteria. It should be added that in some processes presented in the last of the cited paper, alkalization was also due to the emission of $\mathrm{NH}_{4}^{+}$during the decomposition of betaine.

Since, as mentioned above, organic acid biosynthesis occurs primarily during the period of high demand for oxygen in the phase of intensive growth of microorganisms, the largest quantities are formed generally when DOT strongly decreases. According to some reports in the literature, under the micro-aerobic conditions (DOT levels close to zero) acetic acid is often synthesized in large quantities (Krzywonos et al., 2009, 2010; Lasik et al., 2010). In the present studies, the synthesis of acetic acid did not take place in any of the experiments. In the period of increased oxygen demand, all processes were characterized by a definite biosynthesis of butyric acid (Fig. 3). The phenomenon of the synthesis of butyric acid by the Bacillus bacteria with DOT below $50 \%$, but not in micro-aerobic conditions, has also been observed 
by Cibis (2004) during the biodegradation of corn and rye stillage. Similarly to the studies by Krzywonos et al. (2009) and Lasik et al. (2010), in this study most organic acids, synthesized and otherwise, were also assimilated by microorganisms at the end of biodegradation.

For effective wastewater treatment, the important parameter is also the extent of removal of biogens (nitrogen and phosphorus). Too much of their content in the stream of sewage discharged into the environment may lead to eutrophication. In the experiments on beet stillage biodegradation, the highest extent of the removal of both total nitrogen and total phosphorus by a culture of Bacillus bacteria (respectively 56.4 and $58 \%$ ) was observed at $36^{\circ} \mathrm{C}$ (Table 2). Using the same bacterial culture, there was a higher maximum removal of total nitrogen content obtained during biodegradation in the STR bioreactor for beet molasses vinasse (64.8\%) (Ryznar-Luty et al., 2015). It should be noted, however, that the extent of total phosphorus removal(47.8\%) was lower than the extent of total nitrogen removal. In turn, the opposite relationship occurred in the study by Cibis et al. (2002), where total phosphorus removal (57.9\%) was higher than that of total nitrogen removal (28.1\%).

Taking account of both the extent of removal of total nitrogen and total phosphorus, it can be concluded that the results obtained in the case of beet stillage biodegradation were favourable compared to those declared by Cibis et al. (2002) and Ryznar-Luty et al. (2015).

Much lower results than in the present study pertaining to the assimilation of these biogens were achieved by Lasik et al. (2010) in the experiments with the biodegradation of wastewater produced in potato processing plants by the above mentioned bacteria culture, where the extent of removal of both nitrogen and phosphorus does not exceed $21.1 \%$ and $28.9 \%$ respectively.

During the biodegradation at $36^{\circ} \mathrm{C}$ there was also the highest extent of reduction of the phosphate phosphorus content $(60.2 \%)$ in the beet stillage, while in the case of ammonia nitrogen it was $27.7 \%$ (Table 2). A low removal of $\mathrm{N}-\mathrm{NH}_{4}$ content was associated with the low temperature of the process $\left(36^{\circ} \mathrm{C}\right)$. The higher the temperature, the lower the concentration of ammonia nitrogen at the end of the biodegradation process (Table 2). It was due to the fact that, at the elevated temperatures with alkaline $\mathrm{pH}$, the rate of ammonia nitrogen volatilization in the form of $\mathrm{NH}_{3}$ to the atmosphere was higher than the rate of its formation. Thus, $\mathrm{N}-\mathrm{NH}_{4}$ was eliminated from the stillage medium to the highest extent $(71.9 \%)$ at the temperature of $63^{\circ} \mathrm{C}$ (Table 2). A similar influence of temperature on the final concentration of ammonia nitrogen in the stillage medium was observed by Ryznar-Luty et al. (2015). During batch biodegradation processes of beet molasses vinasse (using the same bacteria culture), carried out at the temperatures from 36 to $63^{\circ} \mathrm{C}$, the authors obtained the extent of removal of this biogen from $21.9 \%$ to $100 \%$ respectively.
In summary, a significant impact on the changes in the content of ammonia nitrogen and phosphate phosphorus in the stillage was not only attributed to the phenomenon of proliferation, or autolysis of bacterial cells. At high (uncontrolled) $\mathrm{pH}$, high temperature was the main cause of the decrease in ammonia nitrogen content in the stillage at the end of biodegradation. The concentration of $\mathrm{N}^{-\mathrm{NH}_{4}}$ was also affected by the deamination of proteins (amino acids) present in the stillage, which were not assimilated by the bacteria.

Referring, in turn, to the changes in the phosphate phosphorus content, it can be assumed that they were also caused by hydrolysis or precipitation from the suspension.

\section{CONCLUSIONS}

The effectiveness of the beet stillage biodegradation by the mixed culture of Bacillus bacteria was influenced by the temperature of the process. Under mesophilic conditions, the extents of $\mathrm{SCOD}_{\text {sum }}, \mathrm{BOD}_{5}$ and $\mathrm{TOC}$ reduction were significantly (for $\mathrm{p} \leq 0.05$ ) higher (up to several tens of percent) than under thermophilic conditions.

The highest reduction in $\mathrm{SCOD}_{\text {sum }}(79.9 \%), \mathrm{BOD}_{5}$ $(98.4 \%)$ and TOC $(76.1 \%)$ as well as the highest reduction in total nitrogen $(56.4 \%)$ and total phosphorus $(58 \%)$ was obtained at the temperature of $36^{\circ} \mathrm{C}$. It should be emphasized that the highest efficiency was not associated with the highest biomass production during the biodegradation.

The mixed culture of Bacillus bacteria degraded the sugar beet stillage with similar effectiveness as in previous studies on biodegradation of starch-based stillage (potato, wheat, corn and rye) and beet molasses vinasse.

Aerobic biodegradation of sugar beet distillery stillage can be a first stage in a two- or multi-stage treatment system for this high-strength wastewater on an industrial scale.

\section{REFERENCES}

Akarsubasi, A.T., Ince, O., Oz, N.A., Kirdar, B. and Ince, B.K., Evaluation of performance, acetoclastic methanogenic activity and archaeal composition of full-scale UASB reactors treating alcohol distillery wastewaters. Process Biochemistry, 41, No. 1, 28-35 (2006).

APHA, Standard Methods for the Examination of Water and Wastewater (18th ed.), American Public Health Association. Washington DC (1992).

Beaudet, R., Gagnon, C., Bisaillon, J.G. and Ishaque, M., Microbiological aspects of aerobic thermophilic treatment of swine waste. Applied and Environmental Microbiology, 56, No. 4, 971-976 (1990).

Carta-Escobar, F., Pereda-Marín, J., Álvarez-Mateos, P., RomeroGuzmán, F., Durán-Barrantes, M.M. and Barriga-Mateos, F.,. Aerobic purification of dairy wastewater in continuous regime Part I: Analysis of the biodegradation process in two reactor configurations. Biochemical Engineering Journal, 21, No. 2, 183-191 (2004).

Cibis, E., Aerobic biodegradation of starch stillages from rural distilleries by means of mixed culture of thermo- and mesophilic 
bacteria of the genus Bacillus. PhD thesis, Wroclaw University of Economics (2004).

Cibis, E., Kent, C.A., Krzywonos, M., Garncarek, Z., Garncarek, B. and Miśkiewicz, T., Biodegradation of potato slops from a rural distillery by thermophilic aerobic bacteria. Bioresource Technology, 85, No. 1, 57-61 (2002).

Cibis, E., Krzywonos, M., Trojanowska, K., Miśkiewicz, T. and Ryznar, A., Biodegradation of potato slops with a mixed population of bacteria of the genus Bacillus- determination of the process conditions. Electronic Journal of Polish Agricultural Universities, 7, No.2, 1-13 (2004).

Cibis, E., Ryznar-Luty, A., Krzywonos, M., Lutosławski, K. and Miśkiewicz, T., Betaine removal during thermo- and mesophilic aerobic batch biodegradation of beet molasses vinasse: Influence of temperature and $\mathrm{pH}$ on the progress and efficiency of the process. Journal of Environmental Management, 92, No.7, 1733-1739 (2011).

Decloux, M. and Bories, A., Stillage treatment in the French alcohol fermentation industry. International Sugar Journal, 104, No. 1247, 509-517 (2002).

Decloux, M., Bories, A., Lewandowski, R., Fargues, C., Mersad, A., Lameloise, M.L., Bonnet, F., Dherbecourt, B. and Osuna, L.N., Interest of electrodialysis to reduce potassium level in vinasses. Preliminary experiments. Desalination, 146, No.1-3, 393-398 (2002).

DrLange, Handbook of Photometrical Operation Analysis. (2000).

España-Gamboa, E., Mijangos-Cortes, J., Barahona-Perez, L., Dominguez-Maldonado, J., Hernandez-Zarate, G. and AlzateGaviria, L., Vinasses: characterization and treatments. Waste Management \& Research, 29, No. 12, 1-16 (2011).

Focht, R.L., Schmidt, F.H. and Dowling, B.B., Colorimetric determination of betaine in glutamate process end liquor. Journal of Agricultural and Food Chemistry, 4, No.6, 546-548 (1956).

Fuess, L.T. and Garcia, M.L., Implications of stillage land disposal: A critical review on the impacts of fertigation. Journal of Environmental Management, 145, 210-229 (2014).

Jain, N., Minocha, A.K. and Verma, C.L., Degradation of predigested distillery effluent by isolated bacterial strains. Indian Journal of Experimental Biology, 40, No.1, 101-105 (2002).

Kharayat, Y., Distillery wastewater: bioremediation approaches. Journal of Integrative Environmental Sciences, 9, No.2, 69-91 (2012).

Kosseva, M.R., Fatmawati, A., Palatova, M. and Kent, C.A., Modelling thermophilic cheese whey bioremediation in a onestage process. Biochemical Engineering Journal, 35, No. 3, 281-288 (2007).

Krzywonos, M., Cibis, E., Lasik, M., Nowak, J. and Miśkiewicz, T., Thermo- and mesophilic aerobic batch biodegradation of highstrength distillery wastewater (potato stillage) - Utilisation of main carbon sources. Bioresource Technology, 100, No.9, 2507-2514 (2009).

Krzywonos, M., Cibis, E., Ryznar-Luty, A., Miśkiewicz, T. and Borowiak, D., Aerobic biodegradation of wheat stillage (distillery wastewater) at an elevated temperature-Effect of solids separation. Biochemical Engineering Journal, 49, No.1, 1-6 (2010).

LaPara, T.M., Nakatsu, C.H., Pantea, L.M. and Alleman, J.E., Aerobic biological treatment of a pharmaceutical wastewater:
Effect of temperature on COD removal and bacterial community development. Water Research, 35, No.18, 4417-4425 (2001).

Lasik, M., Nowak, J., Krzywonos, M. and Cibis, E., Impact of batch, repeated-batch (with cell recycle and medium replacement) and continuous processes on the course and efficiency of aerobic thermophilic biodegradation of potato processing wastewater. Bioresource Technology, 101, No.10, 3444-3451 (2010).

Lata, K., Kansal, A., Balakrishnan, M., Rajeshwari, K.V and Kishore, V.V.N., Assessment of biomethanation potential of selected industrial organic effluents in India. Resources Conservation and Recycling, 35, No.3, 147-161 (2002).

Lewicki, W., An introduction to vinasse (cms) from beet and cane molasses fermentation. International Sugar Journal, 103, No.1227, 126-128 (2001).

McDonald, E.J., Sugar analysis. Kirk R. E., Othmar D. F. (eds.). Encyclopedia of Chemical Technology. The Interscience Encyclopedia. New York (1954).

Nandy, T., Shastry, S. and Kaul, S.N., Wastewater management in a cane molasses distillery involving bioresource recovery. Journal of Environmental Management, 65, No.1, 25-38 (2002).

Ogorodnik, S.T. and Stupakova, R.K., Determination of glycerol in wine. Vinodelje, Vinogradarstvo ZSRR, 4, 26-27 (1981).

Rais, M. and Sheoran, A., Treatment of sugarcane industry effluents: science \& technology issues. International Journal of Engineering Research and Applications, 5, No. 1, 11-19 (2015).

REN21, Renewable global status report. Paris (2016). http://www. ren21.net/status-of-renewables/global-status-report/ (accessed 09.06.2016).

Robles-González, V., Galíndez-Mayer, J., Rinderknecht-Seijas, N. and Poggi-Varaldo, H.M., Treatment of mezcal vinasses: A review. Journal of Biotechnology, 157, No.4, 524-546 (2012).

Ryznar-Luty, A., Aerobic biodegradation of beet molasses vinasse by a mixed culture of thermo- and mesophilic bacteria of the genus Bacillus. Dissertation for the Doctoral Degree, Wroclaw University of Economics (2008).

Ryznar-Luty, A., Cibis, E., Krzywonos, M. and Miśkiewicz, T., Efficiency of aerobic biodegradation of beet molasses vinasse under non-controlled $\mathrm{pH}$ : conditions for betaine removal. Archives of Environmental Protection, 41, No.1, 3-14 (2015).

Sánchez, O.J. and Cardona, C.A., Trends in biotechnological production of fuel ethanol from different feedstocks. Bioresource Technology, 99, No.13, 5270-5295 (2008).

Tereos, Annual Report. Lille (2014). http://tereos.com/en/ournews/2014-15-annual-report (accessed 09.06.2016).

Tiirola, M.A., Suvilampi, J.E., Kulomaa, M.S. and Rintala, J.A., Microbial diversity in a thermophilic aerobic biofilm process: analysis by length heterogeneity PCR (LH-PCR). Water Research, 37, No.10, 2259-2268 (2003).

USDA, EU Biofuels Annual Report. Global Agriculture Information Network. Hague (2015). http://gain.fas.usda. gov/Recent\%20GAIN\%20Publications/Forms/AllItems.aspx (accessed 09.06.2016).

Wilkie, A.C., Riedesel, K.J. and Owens, J.M., Stillage characterization and anaerobic treatment of ethanol stillage from conventional and cellulosic feedstocks. Biomass \& Bioenergy, 19, No.2, 63-102 (2000). 